\title{
EFEKTIVITAS LAYANAN BIMBINGAN KELOMPOK DALAM MENINGKATKAN ASERTIVITAS SISWA
}

\author{
Putri Hervita Sari ${ }^{1)}$, Firman ${ }^{2)}$, Syahniar ${ }^{3)}$
}

\begin{abstract}
Nowadays found some student at SMK N 9 Padang prefer to follow a decision of a friend than follow self decision. This research to reveal; 1) the difference assertiveness students group experiment before and after given group guidance 2) the difference assertiveness students the control group before and after without group guidance 3) the difference assertiveness student group experiment given group guidance with student the control group without given group guidance. This research is a quantitative with approach Quasi Experiment Design in type design the Non Equivalent Control Group. The population research was students of X Tata Boga SMK N 9 Padang and samples in this research chosen using a technique purposive sampling. The instrumen used the Questionare. Data then analyzed using Wilcoxon Signed Ranks Test and Kolmogorov Smirnov Two Independent Samples with program computer software Statistical Product and Service Solution (SPSS) Version 20. Based on the research, this research founds; 1) there are significant difference assertiveness students group experiment before and after given guidance group 2) there is no significant difference assertiveness students the control group before and after without given guidance group 3) there are significant difference assertiveness students the experiment group given guidance group with the
\end{abstract} control group without given guidance group.

Keywords: Assertiveness, Guidance Group

\section{PENDAHULUAN}

Pendidikan di Indonesia terus dikembangkan dari waktu-ke waktu agar tercapainya tujuan pendidikan yang tercantum dalam pembukaan UUD 1945. Berbagai kebijakan telah diupayakan agar pendidikan bagi penerus bangsa sesuai dengan tujuan pendidikan yaitu mencerdaskan kehidupan bangsa. Upaya yang telah dilakukan pemerintah yaitu memungkinkan peserta didik dapat belajar dengan mengembangkan kemampuannya. Idealnya, peserta didik dapat belajar dengan mengembangkan seluruh potensi yang ada pada dirinya.

Siswa sebagai generasi penerus bangsa untuk membangun Indonesia dapat memiliki berbagai permasalahan yang mengganggu kehidupan efektif sehari-harinya. Ada beberapa siswa yang dapat mengatasi permasalahannya ada pula siswa yang membutuhkan orang lain untuk membantunya memecahkan masalah. Permasalahan-permasalahan yang dihadapi setiap siswa berbeda-beda sehingga siswa memecahkan masalah juga berbeda-beda. Siswa perlu mengenal kemampuan yang dimilikinya sehingga siswa dapat mengembangkan kemampuannya di lingkungan sekolah. Siswa yang mampu mengenal diri sendiri akan cenderung dapat bertindak degan tepat sesuai dengan kemampuannya. Tidak semua siswa dapat bertindak tepat sesuai dengan kemampuannya. Siswa yang tidak dapat mengenal potensi dirinya sendiri memerlukan orang lain untuk membantunya memahami diri sendiri. Ketidakmampuan siswa dalam mengenal diri merupakan salah satu masalah yang dialami siswa dari sekian banyak masalah yang dapat terjadi di sekolah.

Ada beragam masalah yang dihadapi setiap siswa, baik permasalahan yang berhubungan dengan orang lain maupun masalah yang hanya berkaitan dengan diri sendiri. Salah satu solusi untuk memecahkan masalah yang sangat beragam yaitu bimbingan konseling. Bimbingan konseling merupakan upaya yang dilakukan seorang konselor untuk membantu klien untuk mengatasi hal-hal yang menggangu perkembangan potensi klien, baik yang berasal dari lingkungannya maupun yang berasal dari diri klien sendiri. Konseling menurut Prayitno (2004:105) "proses pemberian bantuan yang dilakukan melalui wawancara konseling oleh seorang ahli (disebut konselor) kepada individu yang sedang mengalami sesuatu masalah (disebut klien) yang bermuara pada teratasinya masalah yang dihadapi klien". Bimbingan

\footnotetext{
${ }^{1}$ Putri Hervita Sari (1), Jurusan Bimbingan dan Konseling, Fakultas Ilmu Pendidikan Universitas Negeri Padang.

${ }^{2}$ Firman (2), Jurusan Bimbingan dan Konseling, Fakultas Ilmu Pendidikan Universitas Negeri Padang

${ }^{3}$ Syahniar (3), Jurusan Bimbingan dan Konseling, Fakultas Ilmu Pendidikan Universitas Negeri Padang
} 
konseling disekolah membantu siswa agar dapat memahami dirinya sehingga dapat memutuskan sikap dan perilaku yang akan diambil sehingga dapat bertanggung jawab terhadap keputusan yang telah diambil.

Jenis-jenis layanan konseling meliputi: layanan orientasi, layanan informasi, layanan penempatan dan penyaluran, layanan penguasaan konten, layanan konseling perorangan, layanan bimbingan kelompok, layanan konseling kelompok, layanan konsultasi, layanan mediasi dan layanan advokasi (Prayitno, 2012:2-3). Bimbingan kelompok merupakan salah satu jenis layanan yang ada pada konseling dengan memanfaatkan dinamika kelompok untuk membahas permasalahan yang terjadi dilingkungan sekitar individu, dari pembahasan tersebut diperoleh pemahaman individu mengenai masalah yang dibahas sehingga membantu individu bertindak sesuai dengan pemahamannya tersebut. Pada bimbingan kelompok setiap anggota berhak mengemukakan pendapatnya masing-masing mengenai topik yang ditugaskan. Anggota dapat mendengar pendapat, informasi ataupun pengalaman-pengalaman dari anggota lain sehingga menambah wawasan anggota mengenai topik. Pada bimbingan kelompok siswa Sekolah Menengah Kejuruan (SMK) sebagai remaja diharapkan berani mengemukakan pendapatnya, karena pada remaja terdapat tugas-tugas perkembangan yang mengharuskan remaja untuk berani mengemukakan pendapat.

Pada masa remaja terdapat tugas-tugas yang harus dicapai siswa sebagai remaja. Tugas perkembangan merupakan tugas yang muncul pada atau sekitar periode tertentu dalam kehidupan individu, pencapaian (tugas perkembangan) yang sukses berperan penting untuk kebahagiannya dan pencapaian tugastugas selanjutnya, sedangkan kegagalan (pencapaian tugas-tugas perkembangan) mengarah timbulnya ketidakbahagiaan dalam diri individu dan sulit untuk mencapai tugas perkembangan selanjutnya. Havighurst dalam Elida Prayitno (2006:42). Salah satu tugas perkembangan remaja, memiliki keterampilan sosial. Asertivitas merupakan suatu keterampilan yang diperlukansiswa agar individu dapat mengemukakan hak-hak, pikiran ataupun perasaan kepada orang lain. Asertivitas diperlukan untuk mengkomunikasikan kepada orang laih hak-hak, pikiran dan perasaan, namun tanpa mengesampingkan hak-hak orang lain. Terkait dengan tugas perkembangan remaja, perilaku asertif merupakan suatu keterampilan untuk menghargai diri sendiri dan orang lain. Remaja yang asertif dapat mengemukakan hakhak, pikiran dan perasaannya kepada orang lain, namun tanpa mengesampingkan hak-hak dari orang lain.

Peserta didik yang memiliki asertivitas yang baik memungkinkannya menegaskan hakhak, pikiran-pikiran dan perasaannya kepada orang lain. Menurut Diana Cawood (1997:30) pasif berbeda dengan asertif. Pasif hanya menerima (menerima pandangan-pandangan dan harapan-harapan setiap orang) tanpa memberikan (tidak menegaskan opini-opini, kebutuhan-kebutuhan, hak-hak)". Asertif memungkinkan seseorang menerima perasaanperasaan dan opini-opini orang lain sementara orang tersebut tetap menjadi hakim bagi tanggapan-tanggapan dan tindakan-tindakannya. Perilaku asertif juga tidak sama dengan agresif. Menyatakan hak-hak, pikiran tanpa dibarengi oleh sikap dan perilaku menghargai hak-hak orang lain akancenderung menjadi perilaku agresif. Perilaku pasif dan agresif berbeda dengan perilaku asertif. Perilaku pasif tanpa adanya perilaku asertif dapat menyebabkan siswa ikut terjerumus kepada hal-hal yang negatif, seperti ikut melanggar peraturan yang berlaku.Siswa dapat terlibat kenakalan remaja, seperti:tawuran, merokok, narkoba dan seks bebas. Berprilaku tanpa menghargai hak orang lain menjadikan seseorang perilaku agresif, seperti mengejek orang lain dan berkata-kata kasar. Dengan adanya perilaku asertif siswa dapat belajar mematuhi peraturantanpa ikutikutan teman melanggar peraturan dan dengan asertivitas siswa dapat menghindari terlibat kenakalan remaja.

Berdasarkan observasi awal yang dilakukan pada hari Selasa tanggal 6 Mei 2014 terhadap kelas $\mathrm{X}$ tata boga adanyabeberapa siswa cenderung mengikuti keputusan temannya. Adanya siswa yang ikut-ikutan melanggar aturan karena tidak bisa menolak ajakan temannya. Beberapa tindakan siswa yang melanggar peraturan sekolah seperti: ikut-ikutan teman terlambat masuk kelas, cabut satu kelas saat pembelajaran berlangsung, ikut-ikutan tidak berseragam rapi, meribut saat pembelajaran berlangsung, meminjamkan teman tugasnya karena takut untuk dikucilkan dan tidak berani menegur teman apabila teman melanggar hakhaknya ataupun melanggar peraturan.

Berdasarkan wawancara dengan guru bimbingan konseling pada hari Rabu tanggal 14 Mei 2014 beberapa siswa tidak sopan berbicara dengan guru yang mengajar dan adanya beberapa siswa yang suka membantah perkataan guru. Tindakan siswa tersebut menjadi penyebab mereka mendapat hukuman dari guru, misalnya tidak diperbolehkan masuk kelas pada jam pelajaran guru tersebut.

Putri Adri Setyowati (2014) melakukan penelitian eksperimen mengenai asertivitas. Pada kelompok eksperimen mendapatkan 
perlakuan dengan layanan bimbingan kelompok selama 8 kali sesi sedangkan untuk kelompok kontrol tidak mendapatkan perlakuan. Topiktopik bimbingan kelompok yang diberikan pada kelompok eksperimen yaitu: lima cara mudah mengenali kepribadian diri sendiri, pengungkapan diri kepada orang lain, menghormati orang lain, pentinngnya bersikap jujur kepada orang lain, pentingnya menyayangi orang lain, pentingnya penolakan dalam kehidupan sehari-hari, pentingnya bertanggung jawab, dan menghargai orang lain. Berdasarkan rata-rata mean sebelum dan sesudah eksperimen ternyata ditemukan adanya peningkatan yang signifikan pada perilaku asertif siswa melalui layanan bimbingan kelompok di SMA Kartika III-1 Banyubiru. Terbukti dari mean sebelum eksperimen 6,00 dan setelah eksperimen menjadi 9,42. Berdasarkan hasil analisa data tersebut, maka tujuan penelitian ini dinyatakan tercapai.Hal itu menunjukkan bahwa layanan bimbingan kelompok dapat meningkatkan perilaku asertif.

Asertivitas yang tepat diperlukan bagi siswa-siswa yang berada pada masa peralihan menuju dewasa. Pada usia remaja siswa dapat belajar untuk berperilaku asertif. Perilaku asertif memungkinkan siswa agar mengungkapkan apa yang ingin diungkapkannya tanpa harus terpaksa mengikuti pendapat orang lain dengan tanpa melanggar hak-hak orang lain. Kenyataan yang ada dilapangan keterampilan untuk berperilaku asertif siswa masih perlu ditingkatkan. Asertivitas siswa perlu ditingkatkan melalui salah satu layanan bimbingan konseling agar siswa dapat belajar untuk berani mengungkapkan pendapat dirinya sehingga siswa tidak terjerumus kepada hal-hal yang merugikan.

Pada penelitian ini, peneliti menggunakan layanan bimbingan kelompok untuk meningkatkan asertivitas siswa. Dinamika kelompok yang terjadi pada bimbingan kelompok dapat membantu siswa untuk berpendapat sesuai pendapatnya sendiri. Siswa dapat mengemukakan apa yang dirasakan atau difikirkannya. Materi-materi yang berkaitan dengan perilaku asertif akan menjadi topik tugas yang akan dibahas pada bimbingan kelompok untuk penelitian ini.

Sesuai dengan fenomena yang telah dikemukakan, peneliti menggunakan salah satu jenis layanan dalam bimbingan konseling yaitu bimbingan kelompok sebagai usaha untuk meningkatkan asertivititas siswa. Dinamika kelompok dalam bimbingan kelompok dimanfaatkan unntuk meningkatkan asertivitas siswa.

\section{METODE PENELITIAN}

Penelitian ini merupakan penelitian eksperimen. Populasi penelitian ini sebanyak 368 orang. Sampel penelitian diambil menggunakan teknik purposive sampling meliputi siswa kelas X Tata Boga 1 dan X Tata Boga 2 sebanyak 20 orang. 10 orang siswa untuk kelompok eksperimen dan 10 orang siswa untuk kelompok kontrol. Instrumen yang digunakan adalah angket dengan lima alternatif jawaban yaitu selalu, sering, kadang-kadang, jarang dan tidak pernah. Teknik analisis data menggunakan presentase (Anas Sudjono, 2009: 318) dengan rumus sebagai berikut:

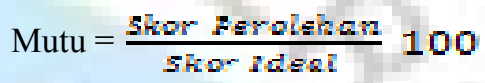

Deskripsi data hasil pretest dan posttest menggunakan teknik statistik yaitu dengan mencari skor mean (rata-rata), standar deviasi, range, skor minimum dan skor maksimum. Menurut Tulus Winarsunu (2002: 59) rumusrumus tersebut adalah:

1. Mean, yaitu $\mathrm{M}=\frac{\Sigma \mathrm{fx}}{\mathrm{N}}$

2. Standar Deviasi, yaitu $\mathrm{SD}=$

$$
\sqrt{\left(\frac{\Sigma \mathrm{fx}^{2}}{\mathrm{~N}}\right)-\left(\frac{\Sigma \mathrm{fx}}{\mathrm{N}}\right)^{2}}
$$

3. Range, yaitu Range $=(\mathrm{Xt}-\mathrm{Xr})+1$

Keterangan:

$\Sigma \mathrm{EX}=$ Jumlah responden yang memilih (frekuensi) x nilai tengah setiap interval.

$\mathrm{N} \quad=$ Jumlah responden

$\mathrm{M}=$ Mean

$\mathrm{SD}=$ Standar Deviasi

Range $=$ Rentangan dari skor

$\mathrm{Xt}=$ Skor Tertinggi

$\mathrm{Xr} \quad=$ Skor Terendah

Data yang didapat kemudian diolah menggunakan rumus statistik dan ditetapkan kriteria penilaian masing-masing data yang diperoleh yang mengacu kepada batasan yang dikemukakan oleh Anas Sudijono (2009: 329):

Tabel 1

Kriteria Pengolahan Data Deskriptif Hasil Penelitian

\begin{tabular}{|c|l|}
\hline Kriteria & \multicolumn{1}{|c|}{ Skor } \\
\hline Sangat Tinggi & Mean+1,5 SD keatas \\
\hline Tinggi & Mean+0,5 SD s/d $<$ Mean+1,5 SD \\
\hline Sedang & Mean-0,5 SD s/d $<$ Mean $+0,5$ SD \\
\hline Rendah & Mean-1,5 SD s/d $<$ Mean-0,5 SD \\
\hline Sangat Rendah & Mean-1,5 SD kebawah \\
\hline
\end{tabular}


Analisis data dengan menggunakan metode teknik statistik non parametrik yaitu Wilcoxon Signed Ranks Test. Test ini digunakan untuk melihat perbedaan asertivitas siswa antara sebelum dan sesudah diberi perlakuan dengan layanan bimbingan kelompok pada kelompok eksperimen dan hanya layanan dari guru bimbingan konseling pada kelompok kontrol. Rumus yang dikemukakan oleh Wahid mengenai Wilcoxon Signed Ranks Test (2003 : 79):

$$
\mathrm{Z}=\frac{T-\mu T}{\sigma T}
$$

Keterangan :

$$
\begin{array}{ll}
\mathrm{T} & =\text { jumlah responden } \\
\mathbf{u T} & =\text { mean } \\
\boldsymbol{\sigma T} & =\text { deviasi standar }
\end{array}
$$

Perbedaan Asertivitas siswa antara kelompok eksperimen yang diberi perlakuan dengan kelompok kontrol yan di beri layanan bimbingan konseling dari guru BK dapat dilihat setelah data dianalisis dengan menggunakan metode teknik statistik non parametrik yaitu: Test Kolmogorov-Smirnov dua sampel, yaitu dengan menggunakan program SPSS versi 20.

\section{HASIL DAN PEMBAHASAN}

\section{Hasil}

Bab ini menguraikan hasil penelitian yang didasarkan pada tujuan penelitian yaitu; 1) menguji perbedaan asertivitas siswa kelompok eksperimen sebelum dan sesudah diberikan layanan bimbingan kelompok; 2) menguji perbedaan asertivitas siswa kelompok kontrol pada sebelum dan sesudah tanpa diberikan layanan bimbingan kelompok; 3) menguji perbedaan asertivitas siswakelompok eksperimen yang diberikan layanan bimbingan kelompok dengan kelompok kontrol yang tidak diberikan layanan bimbingan kelompok.Uraian hasil penelitian akan dijelaskan sebagai berikut:
Perbedaan Asertivitas Siswa Kelompok Eksperimen Pada Pretest dan Posttest Setelah Dilaksanakan Layanan Bimbingan Kelompok

\begin{tabular}{|c|c|c|c|c|c|c|c|}
\hline \multirow{3}{*}{ No } & \multirow{3}{*}{$\begin{array}{c}\text { Kode } \\
\text { Respon } \\
\text { den }\end{array}$} & \multicolumn{6}{|c|}{ Eksperimen } \\
\hline & & \multicolumn{3}{|c|}{ Pretest } & \multicolumn{3}{|c|}{ Postest } \\
\hline & & Skor & $\%$ & $\begin{array}{l}\text { Kate } \\
\text { gori }\end{array}$ & Skor & $\%$ & $\begin{array}{c}\text { Kate } \\
\text { gori }\end{array}$ \\
\hline 1 & IPM & 138 & 69 & $\mathrm{R}$ & 151 & 75,5 & $\mathrm{~S}$ \\
\hline 2 & $\mathrm{RT}$ & 153 & 76,5 & $\mathrm{~S}$ & 166 & 83 & $\mathrm{~T}$ \\
\hline 3 & $\mathrm{AV}$ & 146 & 73 & $\mathrm{~S}$ & 153 & 76,5 & $\mathrm{~S}$ \\
\hline 4 & SPNJ & 148 & 74 & $\mathrm{~S}$ & 158 & 79 & $\mathrm{~T}$ \\
\hline 5 & $\mathrm{NC}$ & 131 & 65,5 & $\mathrm{R}$ & 155 & 77,5 & $S$ \\
\hline 6 & PJL & 152 & 76 & $\mathrm{~S}$ & 165 & 82,5 & $\mathrm{~T}$ \\
\hline 7 & OVCY & 158 & 79 & $\mathrm{~T}$ & 186 & 93 & ST \\
\hline 8 & WF & 129 & 64,5 & $\mathrm{R}$ & 146 & 73 & $\mathrm{~S}$ \\
\hline 9 & PB & 160 & 80 & $\mathrm{~T}$ & 168 & 84 & $\mathrm{~T}$ \\
\hline 10 & WLS & 163 & 81,5 & $T$ & 181 & 90,5 & ST \\
\hline \multicolumn{2}{|c|}{ Jumlah } & 1478 & & & 1629 & & \\
\hline \multicolumn{2}{|c|}{ Mean } & 147,8 & 73,9 & $\mathrm{~S}$ & 81,4 & & $\mathrm{~T}$ \\
\hline
\end{tabular}

Tabel 2

Hasil Pretest dan Posttest Asertivitas Siswa Kelompok Eksperimen

Berdasarkan tabel 2, terjadi peningkatan asertivitas pada keseluruhan siswa dari kelompok eksperimen. Berdasarkan data pretest dan posttest diketahui bahwa adanya peningkatan asertivitas pada kelompok eksperimen setelah diberikan layanan bimbingankelompok.

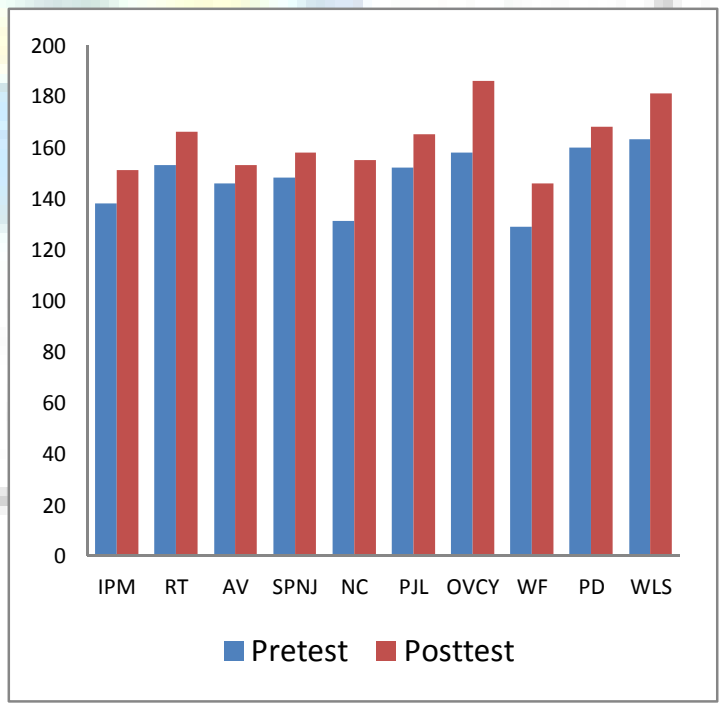

Gambar 1

Gambaran Perbedaan Hasil Pretest dan Posttest Siswa Kelompok Eksperimen 
Pada gambar 1 dijelaskan bahwa adanya peningkatan asertivitas siswa pada seluruh siswa di kelompok eksperimen dari hasil pretest ke posttest. Peningkatan ini terjadi setelah diberikan bimbingan kelompok pada kelompok eksperimen.

Perbedaan Asertivitas Siswa Kelompok Kontrol Pada Pretest dan Posttest Tanpa dilaksanakan Layanan Bimbingan Kelompok

Tabel 3

Hasil Pretest dan Posttest Asertivitas Siswa

\begin{tabular}{|l|l|c|c|c|c|c|c|}
\hline \multirow{2}{*}{ No } & \multirow{2}{*}{$\begin{array}{c}\text { Kode } \\
\text { Respon } \\
\text { den }\end{array}$} & \multicolumn{7}{|c|}{ Kelompok Kontrol } \\
\cline { 3 - 8 } & & Skor & $\%$ & $\begin{array}{c}\text { Kate } \\
\text { gori }\end{array}$ & Skor & $\%$ & $\begin{array}{c}\text { Kate } \\
\text { gori }\end{array}$ \\
\hline 1 & FR & 133 & 66,5 & $\mathrm{R}$ & 125 & 62,5 & $\mathrm{R}$ \\
\hline 2 & $\mathrm{BDP}$ & 158 & 79 & $\mathrm{~T}$ & 163 & 81,5 & $\mathrm{~T}$ \\
\hline 3 & $\mathrm{HT}$ & 124 & 62 & $\mathrm{R}$ & 122 & 61 & $\mathrm{R}$ \\
\hline 4 & $\mathrm{CCD}$ & 131 & 65,5 & $\mathrm{R}$ & 146 & 73 & $\mathrm{~S}$ \\
\hline 5 & $\mathrm{~PB}$ & 145 & 72,5 & $\mathrm{~S}$ & 162 & 81 & $\mathrm{~T}$ \\
\hline 6 & $\mathrm{PE}$ & 144 & 72 & $\mathrm{~S}$ & 139 & 69,5 & $\mathrm{~S}$ \\
\hline 7 & $\mathrm{DPS}$ & 147 & 73,5 & $\mathrm{~S}$ & 124 & 62 & $\mathrm{R}$ \\
\hline 8 & $\mathrm{APD}$ & 162 & 81 & $\mathrm{~T}$ & 168 & 84 & $\mathrm{~T}$ \\
\hline 9 & $\mathrm{PJP}$ & 148 & 74 & $\mathrm{~S}$ & 152 & 76 & $\mathrm{~S}$ \\
\hline 10 & $\mathrm{KT}$ & 164 & 82 & $\mathrm{~T}$ & 167 & 83,5 & $\mathrm{~T}$ \\
\hline Jumlahy & 1456 & & & 1468 & & \\
\hline Mean & & 145,6 & 72,8 & $\mathrm{~S}$ & 73,4 & & $\mathrm{~S}$ \\
\hline
\end{tabular}

Berdasarkan data pretest dan posttest yang terlihat pada tabel 3, dapat disimpulkan adanya peningkatan kategori pada dua orang dari sepuluh orang di kelompok kontrol, sedangkan pada tujuh orang lainnya mengalami asertivitas pada kategori yang tetap dan pada satu orang lainnya mengalami penurunan pada kategori asertivitas. Jika ditinjau dari skor asertivitas siswa pada pretest dan posttest, maka terjadi peningkatan skor asertivitas siswa pada enam orang siswa dan terjadi penurunan asertivitas siswa pada empat orang dari sepuluh orang di kelompok kontrol.

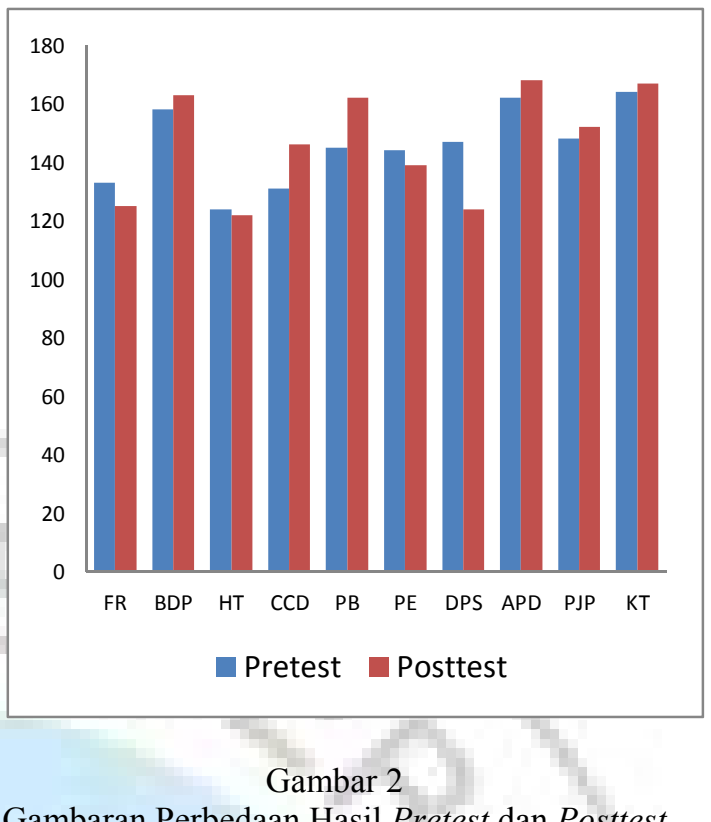

Gambaran Perbedaan Hasil Pretest dan Posttest Siswa Kelompok Kontrol

Pada gambar 2 dijelaskan bahwa ada peningkatan dan penurunan skor asertivitas siswa pada kelompok kontrol. Ada enam orang siswa di kelompok kontrol yang mengalami peningkatan asertivitas dan ada empat orang siswa di kelompok kontrol yang mengalami penurunan asertivitas.

Perbedaan Peningkatan Asertivitas Siswa Pada Kelompok Eksperimen dengan Kelompok Kontrol

Tabel 4

Hasil Pretest dan Posttest Kelompok Eksperimen dengan Kelompok Kontrol

\begin{tabular}{|c|c|c|c|c|c|c|}
\hline \multirow[t]{2}{*}{ No } & \multirow{2}{*}{$\begin{array}{c}\text { Kode } \\
\text { Respon } \\
\text { den }\end{array}$} & \multicolumn{2}{|c|}{ Eksperimen } & \multirow{2}{*}{$\begin{array}{c}\text { Kode } \\
\text { Respon } \\
\text { den }\end{array}$} & \multicolumn{2}{|c|}{ Kontrol } \\
\hline & & Pretest & Posttest & & Pretest & Postest \\
\hline 1 & IPM & 138 & 151 & FR & 133 & 125 \\
\hline 2 & RT & 153 & 166 & $\mathrm{BDP}$ & 158 & 163 \\
\hline 3 & $\mathrm{AV}$ & 146 & 153 & HT & 124 & 122 \\
\hline 4 & SPNJ & 148 & 158 & $\mathrm{CCD}$ & 131 & 146 \\
\hline 5 & $\mathrm{NC}$ & 131 & 155 & $\mathrm{~PB}$ & 145 & 162 \\
\hline 6 & PJL & 152 & 165 & $\mathrm{PE}$ & 144 & 139 \\
\hline 7 & OVCY & 158 & 186 & DPS & 147 & 124 \\
\hline 8 & WF & 129 & 146 & APD & 162 & 168 \\
\hline 9 & PB & 160 & 168 & PJP & 148 & 152 \\
\hline 10 & WLS & 163 & 181 & KT & 164 & 167 \\
\hline \multicolumn{2}{|c|}{ Jumlah } & 1478 & 1629 & & 1456 & 1469 \\
\hline \multicolumn{2}{|c|}{ Mean } & 147,8 & 81,4 & & 145,6 & 73,4 \\
\hline \multicolumn{2}{|c|}{ Kategori } & $\mathrm{S}$ & $\mathrm{T}$ & & $\mathrm{S}$ & $\mathrm{S}$ \\
\hline
\end{tabular}


Berdasarkan data pretest dan posttest yang dapat dilihat pada tabel 4 diketahui bahwa terjadi peningkatan asertivitas setelah diberikan layanan bimbingan kelompok pada kelompok eksperimen dan juga adanya peningkatan asertivitas siswa setelah dibarikan layanan bimbingan konseling dari guru bimbingan konseling di sekolah pada kelompok kontrol. Peningkatan asertivitas pada kelompok eksperimen lebih besar dibandingkan peningkatan pada kelompok kontrol. Selain itu dari tabel dapat dilihat bahwa hampir keseluruhan siswa pada kelompok eksperimen mengalami peningkatan setelah diberikan layanan bimbingan kelompok, sedangkan pada kelompok kontrol masih terdapat beberapa siswa yang tidak mengalami peningkatan asertivitas. Hal ini berarti bahwa pemberian layanan bimbingan kelompok lebih efektif dalam meningkatkan asertivitas siswa.

\section{Pembahasan}

Pembahasan hasil temuan penelitian yang dapat diuraikan sebagai berikut:

Perbedaan Asertivitas Siswa Kelompok Eksperimen Sebelum dan Sesudah Diberikan Layanan Bimbingan Kelompok

Pada penelitian ini, hipotesis pertama yang akan diuji yaitu "terdapat perbedaan yang signifikan kelompok eksperimen sebelum dan sesudah diberikan layanan bimbingan kelompok". Pengujian hipotesis pertama menggunakan analisis Wilcoxon Signed Rank Test dengan bantuan program komputer SPSS versi 20. Angka Asymp.Sig.(2-tailed) asertivitas siswa pada kelompok eksperimen sebesar 0,005 atau probalitas dibawah alpha 0,05 . Berdasarkan hasil pengolahan tersebut, maka $\mathrm{H} 0$ ditolak dan H1 diterima yaitu "Terdapat perbedaan yang asertivitas siswa pada kelompok eksperimen sebelum dan setelah diberikan perlakuan layanan bimbingan kelompok.

Berdasarkan hasil penelitian yang dilakukan melalui eksperimen dengan topik tugas yang berkenaan dengan asertivitas siswa, ternyata asertivitas siswa kelompok eksperimen secara keseluruhan menunjukkan adanya perbedaan secara signifikan antara sebelum dan sesudah mengikuti bimbingan kelompok. Hal tersebut berarti layanan bimbingan kelompok efektif meningkatkan asertivitas siswa.

Salah satu tujuan bimbingan kelompok menurut Prayitno (2012:150) yaitu berkembangnya kemampuan sosialisasi siswa, khususnya kemampuan komunikasi peserta layanan. Pada bimbingan kelompok yang dilaksanakan, anggota kelompok dapat melatih kemampuannya untuk mengkomunikasikan hak- haknya untuk menyampaikan pendapat sebagai upaya untuk meningkatkan asertivitas siswa.

Dean H. Hepworth \& Jo Ann Larsen (1982: 389) mengemukakan jika pelaksana pada sebuah kelompok bersikap tenang dan menunjukkan melalui perilaku yang menentukan bahwa pelaksana mampu sepenuhnya menangani masalah-masalah yan terjadi dalam kelompok terkait anggota kelompok, memberikan perlindungan dan mampu untuk mengontrol proses yang berpotensi kacau atau tidak stabil, anggota umumnya juga akan tenang, berharap ia dapat dihargai dan mulai menerapkan asertivitas. Jika pelaksana tidak mampu menghindari proses gangguan yang membuat anggota dikritik oleh anggota lain, anggota akan memiliki keraguan karena anggota akan berfikir bahwa ia menempatkan dirinya dalam resiko dikritik dan akibatnya anggota tidak menerapkan asertivitasnya. Pendapat tersebut menunjukkan bahwa dengan kemampuan yang dimiliki oleh pemimpin kelompok dalam memimpin kelompok dari awal kegiatan hingga akhir kegiatan bimbingan kelompok menentukan efektifnya bimbingan kelompok.

Perbedaan Asertivitas Siswa Kelompok Kontrol Sebelum dan Sesudah Tanpa Diberikan Layanan Bimbingan Kelompok

Hipotesis kedua dalam penelitian ini adalah "tidak terdapat perbedaan yang signifikan asertivitas siswa kelompok kontrol yang tidak diberikan layanan bimbingan kelompok". Pengujian hipotesis diuji dengan menggunakan analisis Wilcoxon Signed Ranks Test. Analisis melalui program komputer SPSS versi 20. Angka probabilitas Asymp. Sig.(2tailed) asertivitas siswa pada kelompok kontrol sebesar 0,610 atau probabilitas di atas alpha $\mathbf{0 , 0 5}$ dari hasil tersebut maka $\mathrm{H} 0$ diterima dan $\mathrm{H} 1$ ditolak. Berdasarkan penjelasan terserbut, maka hipotesis kedua pada penelitian ini tidak diterima, yaitu "Tidak terdapat perbedaan yang signifikan asertivitas siswa kelompok kontrol yang tidak diberi perlakuan bimbingan kelompok".

Berdasarkan hasil pengujian dengan Wilcoxon Signed Ranks Test yang telah dilakukan berarti bahwa dari 10 responden kelompok kontrol yang dilibatkan dalam perhitungan, hanya enam orang siswa yang mengalami peningkatan dari pretest ke postest. Sedangkan empat orang siswa mengalami penurunan dari Pretest ke Posttest. Berdasarkan hasil pengujian hipotesis tersebut dapat diartikan bahwa pada kelompok kontrol hanya sebagian siswa yang mengalami peningkatan yang baik dalam hal asertivitas siswa. 
Berdasarkan data hasil uji hipotesis posttest dari kelompok kontrol yang berjumlah 10 orang siswa terdapat 6 orang yang mengalami peningkatan skor asertivitas sedangkan yang mengalami penurunan terdapat 4 orang siswa. Hal yang terjadi pada kelas kontrol terjadi dikarenakan siswa tidak mendapatkan perlakuan khusus yaitu bimbingan kelompok melainkan hanya mendapatkan layanan dari guru BK di sekolah saja. b. tidak terdapat perbedaan yang signifikan asertivitas siswa kelompok kontrol tanpa diberikan layanan bimbingan kelompok.

c. terdapat perbedaan yang signifikan asertivitas siswa kelompok eksperimen yang diberikan layanan bimbingan kelompok dengan kelompok kontrol yang tidak diberikan layanan bimbingan kelompok.

\section{Perbedaan Peningkatan Asertivitas Siswa Kelompok Eksperimen yang Diberikan Layanan Bimbingan Kelompok dengan Siswa Kelompok yang Tidak Diberikan Layanan Bimbingan Kelompok}

Hipotesis ketiga yang diajukan dalam penelitian ini yaitu "Terdapat perbedaan yang signifikan asertivitas siswa kelompok eksperimen yang mengikuti layanan bimbingan kelompok dengan siswa kelompok kontrol yang tidak diberikan layanan bimbingan kelompok". Pengujian hipotesis dengan menggunakan teknik analisis Two Sample Kolmogorov Smirnov Test melalui program komputer SPSS versi 20. Asymp.sig. (2-tailed)/significance untuk uji dua sisi adalah 0.003 Maka H0 ditolak dan H1 diterima. Hal ini berarti bahwa terdapat perbedaan yang signifikan asertivitas siswa kelompok eksperimen yang diberikan layanan bimbingan kelompok dengan siswa kelompok kontrol yang tidak diberikan layanan bimbingan kelompok. Terkait hipotesis ketiga yang menyatakan "Terdapat perbedaan yang signifikan asertivitas kelompok eksperimen yang diberikan layanan bimbingan kelompok dengan siswa kelompok kontrol yang tidak diberikan layanan bimbingan kelompok". dapat diterima.

Menurut Prayinto, dkk (1997:102) tujuan bimbingan kelompok yaitu "agar masing-masing anggota dapat mengemukakan apa yang dipikirkan dan dirasakannya serta memperoleh tanggapan dan reaksi dari anggota lainnya". Pendapat tersebut menyatakan bahwa pada bimbingan kelompok anggota dapat belajar untuk mengemukakan pikiran dan perasaan dengan menghargai anggota kelompok lain, hal ini merupakan suatu kondisi yang dapat menjadikan asertivitas dapat ditingkatkan melalui bimbingan kelompok.

\section{KESIMPULAN DAN SARAN}

\section{Kesimpulan}

Temuan dari penelitian ini yaitu:

a. terdapat perbedaan yang signifikan asertivitas siswa kelompok eksperimen sebelum dan sesudah diberikan bimbingan kelompok.
2. Saran

a. guru bimbingan konseling diharapkan untuk terus meningkatkan dan mengembangkan layanan bimbingan dan konseling terutama layanan bimbingan konseling. Dinamika kelompok yang ada pada bimbingan konseling dapat dimanfaatkan untuk meningkatkan asertivitas siswa.

b. kepala SMK N 9 Padang diharapkan untuk lebih memperhatikan layanan bimbingan dan konseling terutama dalam penyediaan dan pengadaan sarana belajar umumnya seperti alatalat yang dibutuhkan guru BK dalam membantu mengembangkan kompetensi siswa dan mendorong guru BK untuk melaksanakan layanan bimbingan kelompok.

c. kepala Dinas Pendidikan Provinsi Sumatera Barat sebagai referensi guna meningkatkan kinerja dan kompetensi guru BK.

d. ketua Jurusan Bimbingan dan Konseling Fakultas Ilmu Pendidikan Universitas Negeri Padang, sebagai referensi untuk mempersiapkan rancangan program bimbingan konseling, khususnya bimbingan kelompok.

e. bagi peserta didik, diharapkan dapat lebih meningkatkan asertivitas baik di sekolah maupun di luar sekolah serta dapat berpartisipasi dan berperan aktif untuk mengikuti kegiatan yang dilakukan oleh guru BK di sekolah.

f. bagi peneliti selanjutnya, diharapkan dapat melanjutkan penelitian tentang asertivitas dan melakukan penelitian dengan jenis layanan bimbingan dan konseling yang lainnya. 


\section{KEPUSTAKAAN}

Anas Sudijono. 1998. Pengantar Statistik Pendidikan.. Jakarta: Rajawali Press.

Cawood, Diana. 1997. Manajer yang Asertif. (Alih Bahasa: Bern Hidayat). Jakarta: Gramedia.

Hepworth, Dean H \& Jo Ann Larsen. 1982. Direct Social Work Practice. USA: The Dorsey Press.

Elida Prayitno. 2006. Psikologi Perkembangan Remaja. Padang: Angkasa Raya.

Prayitno. 1997. Pelayanan Bimbingan dan Konseling (Seri Pemandu Pelaksanaan Bimbingan Konseling di SMP). Padang: BK FIP UNP.

Prayitno. 2004. Dasar-dasar Bimbingan Konseling. Jakarta: Rineka Cipta.
Prayitno. 2012. Jenis Layanan dan Kegiatan Pendukung Konseling. Padang: Program PPK BK FIP UNP.

Putri Adri Setyowati. 2014. "Meningkatkan Perilaku Asertif Siswa Kelas X SMA Kartika III-1 Banyubiru melalui Layanan Bimbingan Kelompok". Skripsi. (online), http://repository.library.uksw.edu, diakses 20.30 WIB tanggal 29 Maret 2015).

Tulus Winarsunu. 2002. Statistik dalam Penelitian Psikologi \& Pendidikan. Malang: UMM Press.

Wahid Sulaiman. 2003. Statistik Non Parametrik. Yogyakarta: Andi

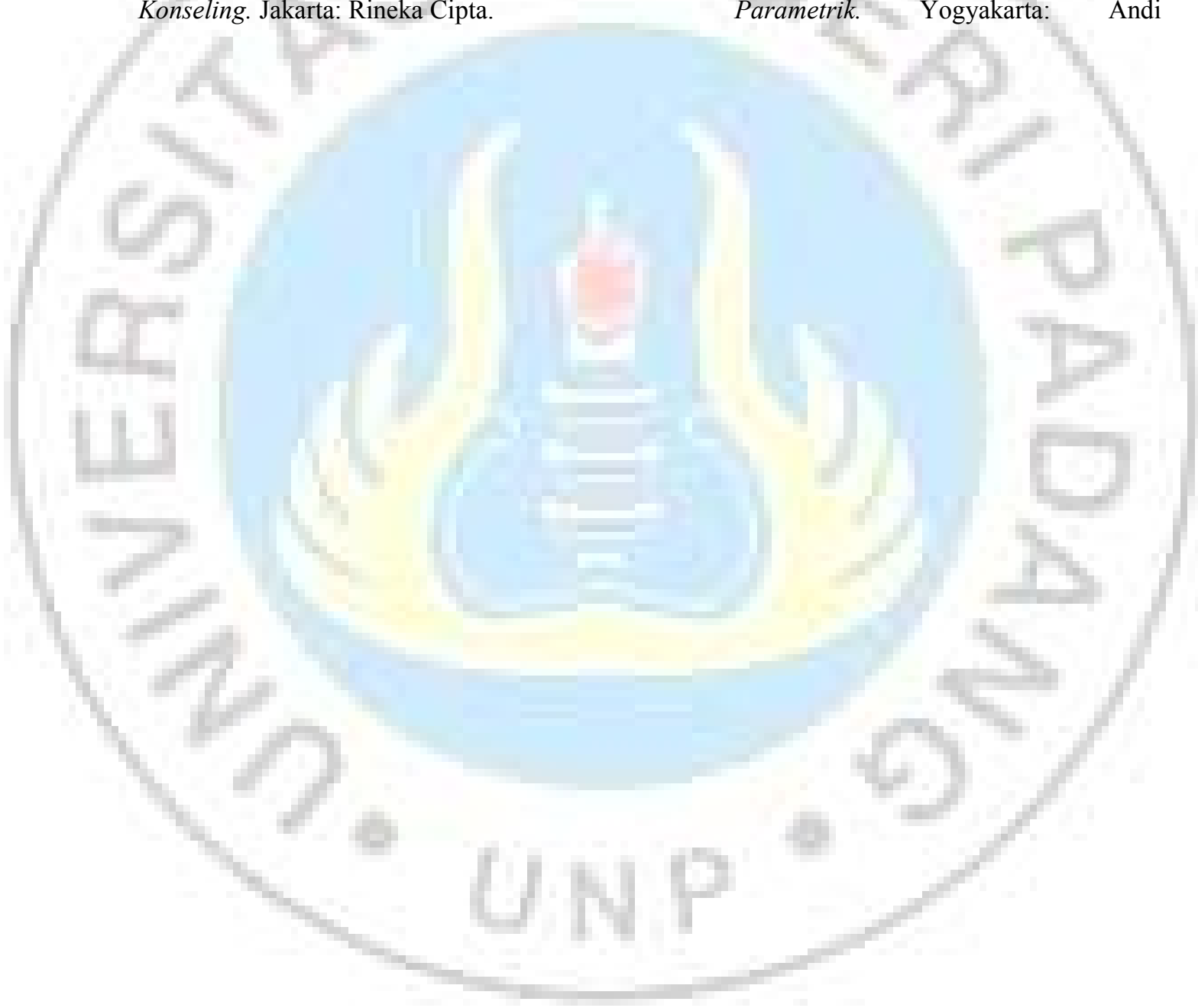

